\title{
Peran Bifidobacterium dalam Perkembangan Otak dan Tumbuh Kembang Anak
}

\author{
Ahmad Suryawan, ${ }^{1}$ Rini Sekartini ${ }^{2}$ \\ ${ }^{1}$ Departemen Ilmu Kesehatan Anak, Fakultas Kedokteran Universitas Airlangga, RSUD Dr. Sutomo, Surabaya \\ ${ }^{2}$ Departemen Ilmu Kesehatan Anak, Fakultas Kedokteran Universitas Indonesia, RSUP Dr. Cipto Mangunkusumo, Jakarta
}

Pengetahuan tentang peran spesifik mikrobiota saluran cerna dalam perkembangan otak dan tumbuh kembang anak semakin menarik perhatian peneliti pada beberapa tahun terakhir. Hal tersebut disebabkan karena terakumulasinya bukti dari berbagai studi tentang komunikasi dua arah antara saluran cerna dan otak, yang digambarkan sebagai teori gut-brain axis. Salah satu mikrobiota yang mendapat perhatian khusus dalam hal ini adalah Bifidobacterium, yang berpotensi mempunyai peran khusus dalam perkembangan otak anak usia dini, Kolonisasi Bifidobacterium dalam saluran cerna paling dominan pada usia awal setelah lahir, yang terjadi paralel dengan periode kritis perkembangan sirkuit otak anak. Aplikasi klinis teori gut-brain axis lebih banyak terbukti pada studi eksperimental. Studi pada subyek anak mayoritas merupakan studi observasional dengan hasil yang tidak konsisten. Pemberian Bifidobacterium nampak menjanjikan sebagai regimen untuk terapi gejala gangguan tumbuh kembang. Namun bukti berbasis uji klinis masih sangat terbatas, dan menunjukkan hasil yang heterogen. Masih diperlukan bukti berbasis uji klinis acak-terkontrol yang dirancang dengan baik untuk memvalidasi efektivitas probiotik untuk terapi gangguan tumbuh kembang dalam hal identifikasi strain, dosis, dan waktu pengobatan yang sesuai dan standar. Peningkatan pemahaman tentang keilmuan gut-brain axis diharapkan membuka kemungkinan dimasa depan akan muncul terapi berbasis probiotik yang mempunyai efek terhadap berbagai kondisi otak dan tumbuh kembang anak. Sari Pediatri 2021;22(5):325-30

Kata kunci: Bifidobacterium, otak, tumbuh kembang, anak

\section{The Role of Bifidobacterium in Brain Development and Child Development}

\begin{abstract}
Ahmad Suryawan, ${ }^{1}$ Rini Sekartini ${ }^{2}$
Knowledge of the specific role of the gut microbiota on brain and child development has attracted the attention of researchers due to accumulating evidence from studies on two-way communication between the gastrointestinal tract and the brain, which is described as the gut-brain axis theory. One of the microbiota that has received special attention is Bifidobacterium, which has the potential role in early childhood brain development. Bifidobacterium colonization in the gut is most dominant at an early age after birth, which occurs parallel to the critical period of brain development. The clinical application of the gut-brain axis theory is proven in experimental studies. Majority studies on child are observational with inconsistent results. Administration of Bifidobacterium appears promising as a regimen for the treatment of developmental disorders. However, clinical trial-based evidence is still very limited, and shows heterogeneous results. There is still a need for well-designed randomized-controlled clinical trials to validate the effectiveness of probiotics for the treatment of developmental disorders in terms of identifying standardized strains, dosages, and treatment times. Understanding of the gut-brain axis science is expected to open up the possibility that in the future there will be probiotic-based therapies that have an effect on brain and child development. Sari Pediatri 2021;22(5):325-30
\end{abstract}

Keywords: Bifidobacterium, brain, growth development, child

Alamat korespondensi: Ahmad Suryawan. Departemen Ilmu Kesehatan Anak Fakultas Kedokteran Universitas Airlangga / Rumah Sakit Umum Daerah Dr. Soetomo, Surabaya. Email: abmad.suryawan@fk.unair.ac.id 
S ejumlah studi saat ini membuktikan adanya interaksi dua arah antara sistem saraf pusat dengan sistem saraf enteral dalam saluran cerna melalui sebuah mekanisme yang dikenal dengan gut-brain axis. Interaksi ini secara fungsional diperankan oleh mikrobiota saluran cerna yang dapat memberikan sinyal ke otak dan memengaruhi berbagai proses yang terkait dengan perkembangan perilaku dan kecerdasan anak. ${ }^{1-2}$ Bukti studi eksperimental in-vitro dan uji klinis in-vivo mendukung adanya peran spesifik dari mikrobiota saluran cerna dalam perkembangan otak dan tumbuh kembang anak. Namun demikian, masih belum terdapat bukti yang jelas apakah manipulasi komposisi mikrobiota saluran cerna melalui pemberian probiotik dan/atau prebiotik mempunyai dampak positif pada manajemen berbagai gangguan perkembangan anak. ${ }^{1}$

Peningkatan pemahaman tentang keilmuan gutbrain axis akan membuka kemungkinan munculnya regimen psychobiotic, yakni terapi berbasis probiotik yang mempunyai efek terhadap berbagai kondisi otak dan tumbuh kembang anak. ${ }^{2}$ Sehingga saat ini penggunaan mikrobiota saluran cerna sebagai agen terapeutik semakin menjadi pusat perhatian para peneliti. ${ }^{1}$ Tinjauan yang bersifat naratif ini bertujuan untuk mengulas peran mikrobiota saluran cerna dan probiotik dalam perkembangan otak dan tumbuh kembang anak, dengan penekanan pada peran Bifidobacterium.

\section{Peran dalam pertumbuhan anak}

Tinjauan sistematik oleh Onubi $\mathrm{dkk}^{3}$ tahun 2015, merupakan bukti komprehensif pertama yang melaporkan efek probiotik terhadap terhadap beberapa parameter pertumbuhan anak pada kondisi non-spesifik, efek probiotik terhadap pertumbuhan anak dianalisis tanpa memandang jenis regimen yang digunakan sebagai pembawa probiotik tersebut, apakah susu formula, atau lainnya. Berbagai variasi dalam studi ini meliputi jenis, jumlah dan durasi probiotik yang diberikan, karakteristik anak, dan parameter luaran.

Secara keseluruhan dapat disimpulkan bahwa 5 studi menemukan adanya efek positif dari probiotik terhadap pertumbuhan anak. Kelima studi ini dilakukan pada anak di negara sedang berkembang, dengan 4 studi pada komunitas anak gizi kurang dan
1 studi pada kelompok anak gizi normal. Salah satu studi yang dimasukkan adalah berasal dari Indonesia, yang membuktikan bahwa pemberian kombinasi prebiotik dan probiotik Bifdobacterium longum BB536 dan Lactobacillus rhamnosus dalam susu formula mempunyai efek positif terhadap peningkatan berat badan anak. ${ }^{4}$ Sementara itu, dari 7 studi yang dilakukan pada anak di negara maju, kesemuanya menunjukkan bukti bahwa pemberian probiotik tidak mempunyai efek yang signifikan terhadap pertumbuhan anak. ${ }^{3}$

Keamanan dari efek pemberian probiotik terhadap pertumbuhan anak terbukti dari berbagai studi. Pada uji acak terkontrol menunjukkan bukti bahwa pola pertumbuhan berat badan, panjang badan, dan lingkar kepala bayi yang mendapatkan formula dengan kandungan Bifidobacterium longum BB 536 menunjukkan pola pertumbuhan yang serupa dibandingkan kelompok bayi penerima forrmula kontrol, ${ }^{5}$ dan sebanding dengan grafik WHO sebagai cerminan pertumbuhan anak yang mendapatkan ASI. ${ }^{6}$

Pola pertumbuhan bayi cukup bulan yang diberikan formula mengandung Lactobacillus rhamnosus LCS742 and Bifidobacterium longum subsp infantis M63, menunjukkan pola pertumbuhan yang serupa dan mirip dengan kelompok bayi kontrol. ${ }^{7}$ Pemberian formula hidrolisa-ekstensif yang mengandung sinbiotik dengan probiotik Bifidobacterium breve M-16V pada bayi cukup bulan dapat mendukung pertumbuhan berat badan dan tinggi badan yang adekuat sesuai dengan grafik pertumbuhan standar WHO. ${ }^{8}$

Sementara itu, berbagai studi eksperimental maupun studi pada manusia menunjukkan kemungkinan Bifidobacterium mempunyai kapabilitas menurunkan kadar lemak dan bersifat anti obesitas. ${ }^{9-10}$ Hal tersebut juga didukung dengan studi bahwa anak yang tumbuh dengan berat badan lebih atau obesitas mempunyai kolonisasi dominan golongan Firmicutes, sebaliknya anak dengan berat badan normal didominasi oleh Bifidobacterium. ${ }^{11}$

\section{Peran dalam perkembangan, perilaku, dan kecerdasan anak}

Studi tentang peran mikrobiota atau probiotik pada perkembangan perilaku anak lebih banyak dilakukan pada anak dengan ADHD dan Autism Spectrum Disorders (ASD). Anak dengan ASD 
mempunyai karakteristik perilaku stereotipi dan defisit dalam komunikasi dan interaksi sosial. Salah satu komorbiditas utama yang terkait dengan ASD adalah disfungsi gastrointestinal sehingga membuka adanya potensi peran dari mikrobiota saluran cerna dalam patofisiologi ASD. Namun, saat ini belum terdapat sebuah konsensus tentang spesies bakteri tertentu yang mengalami perubahan komposisi di setiap studi yang pernah dilakukan pada anak dengan ASD. Beberapa ahli mensinyalir bahwa suplementasi diet berbasis probiotik adalah salah satu terapi yang potensial untuk anak dengan ASD di masa depan, karena anak dengan ASD mempunyai karakteristik mempunyai selektivitas yang kuat terhadap makanan tertentu yang sangat memengaruhi komposisi mikrobiota saluran cernanya. ${ }^{12}$

Studi eksperimental binatang coba membuktikan bahwa komposisi mikrobiota saluran cerna yang didominasi oleh Bifidobacterium pada awal kehidupan mempunyai efek jangka panjang pada perilaku di masa dewasa. ${ }^{13}$ Studi pada subyek bayi menunjukkan bahwa mikrobiota saluran cerna kemungkinan memengaruhi fungsi otak berdasarkan adanya bukti bahwa pemberian probiotik pada usia awal kehidupan dapat menurunkan risiko gangguan perilaku di kemudian hari dengan mekanisme mungkin yang tidak hanya melibatkan mikrobiota saja. Pada bayi yang diketahui mempunyai jumlah kandungan spesies Bifidobacterium di dalam saluran cerna lebih rendah secara signifikan dibandingkan anak sehat normal pada usia 6 bulan pertama, mempunyai risiko lebih tinggi mengalami gangguan perilaku attention deficit hyperactive disorders (ADHD) atau Asperger Syndrome pada saat usia 13 tahun. ${ }^{14}$

Keterkaitan antara probiotik dengan perkembangan perilaku anak sudah terlihat sejak usia awal bayi. Jumlah Bifidobacterium dan Lactobacillus mempunyai hubungan dengan kondisi distres bayi (menangis dan rewel). Proporsi jumlah Bifidobacterium dibandingkan jumlah total bakteri berbanding terbalik dengan frekuensi rewel dan menangis bayi pada usia 3 bulan pertama. Meskipun demikian masih diperlukan studi yang mengeksplorasi jenis strain dari probiotik tersebut. ${ }^{15}$

Tinjauan sistematik dari 10 penelitian observasional kasus-kontrol yang bertujuan untuk mengidentifikasi adanya karakteristik dan jenis mikrobiota yang khas pada anak dengan gangguan perilaku (2 studi untuk anak ADHD; 8 studi untuk anak ASD), menunjukkan hasil yang tidak konklusif dengan validitas eksternal yang sangat terbatas, terjadi heterogenitas yang sangat tinggi dalam hal besar subyek, jenis kelamin, kondisi klinis, dan jenis kelompok kontrol. Dengan demikian, masih dibutuhkan berbagai studi dengan kualitas bukti lebih tinggi seperti studi kohort. ${ }^{16}$

Studi pada komunitas anak berusia 2-7 tahun menunjukkan bahwa pada pada kelompok anak dengan ASD mempunyai komposisi mikrobiota saluran cerna Bifidobacterium yang lebih rendah dibandingkan kelompok kontrol. ${ }^{17}$ Sementara studi pada level keluarga membuktikan bahwa individu dengan ASD mempunyai diversitas atau keragaman mikrobiota yang lebih sedikit dibandingkan anggota keluarga lainnya yang tidak mengalami ASD. ${ }^{18}$

Meta-analisis dari Xu, ${ }^{19}$ tahun 2019 , memerlihatkan bahwa anak dengan ASD mempunyai komposisi mikrobiota saluran cerna yang lebih tinggi untuk Faecalibacterium dan Lactobacillus, sedikit meningkat untuk Ruminococcus dan Clostridium, dan lebih rendah untuk Akkermansia, Bacteroides, Bifidobacterium, dan Enterococcus, dibandingkan anak yang perkembangannya normal.

Namun, pada tinjauan sistematik dari 26 studi terkini tentang disbiosis mikrobota saluran cerna pada anak dengan ASD tidak dihasilkan kesimpulan yang konklusif untuk dapat digunakan sebagai tanda khas untuk memprediksi kondisi atau gejala ASD. Selain itu, masih belum ditemukan konsistensi dalam hal perubahan mikrobiota saluran cerna pada anak dengan ASD, kecuali untuk perubahan komposisi Prevotella, Firmicutes di tingkat filum, kluster Clostridiales termasuk Clostridium perfringens, dan spesies Bifidobacterium pada anak dengan ASD. Hasil ini akan sangat berguna dalam merancang studi pengaruh mikrobiota terhadap ASD di masa depan. Masih dibutuhkan berbagai studi yang dapat menjelaskan peran spesifik mikrobiota saluran cerna dalam patogenesis ASD pada anak. ${ }^{20}$

Dengan demikian dapat dikatakan bahwa meskipun dari berbagai studi pre-klinik dan uji klinis menunjukkan hasil yang menjanjikan, tetapi secara umum efikasi pemberian probiotik untuk manajemen perilaku pada anak dengan ASD masih sangat terbatas. Terlebih pula, masih belum terdapat standarisasi regimen dalam hal strain, dosis, dan durasi pemberian probiotik tersebut. ${ }^{21}$ Bila pengetahuan tentang bagaimana efek mikrobiota terhadap otak dapat diketahui lebih dalam, maka tidak menutup 
kemungkinan di masa depan akan didapatkan spesies Bifidobacterium yang diberikan ke dalam nutrisi bayi untuk memeroleh efek yang diinginkan pada otak anak. ${ }^{13}$

Sementara itu, anak dengan ADHD mempunyai karakteristik perilaku yang ditandai dengan hiperaktivitas dan/atau impulsif, inatensi, atau kombinasi semuanya. Studi literatur mengungkapkan bahwa pada populasi anak ADHD mempunyai komposisi mikrobiota saluran cerna yang berbeda, yakni rendahnya kolonisasi mikrobiota yang termasuk filum Actinobacteria dan Firmicutes, dibandingkan pada populasi anak normal. Genus Bifidobacterium, yang termasuk di dalam filum Actinobacteria, nampaknya berperan penting dalam patogenesis ADHD dalam hal memengaruhi sistem produksi dopamin. Akan tetapi, potensi Bifidobacterium sebagai biomarker untuk menegakkan diagnosis ADHD masih menghadapi berbagai kendala oleh karena perbedaan level Bifidobacterium yang bervariasi antar penderita ADHD. Masih dibutuhkan studi di masa depan yang mampu secara definitif membuktikan korelasi antara level Bifidobacterium dan ADHD. ${ }^{22}$

Selain keterkaitan dengan perilaku anak, studi yang memelajari korelasi antara mikrobiota saluran cerna dengan perkembangan dasar anak masih belum banyak ditemui. Salah satunya adalah dari Sordillo $\mathrm{dkk}^{23}$ tahun 2019, yang menilai korelasi antara komposisi mikrobiota saluran cerna bayi di usia 3-6 bulan dengan status perkembangan anak saat berusia 3 tahun yang dinilai menggunakan instrumen ages and stages questionnaire, edisi ke-3 (ASQ-3).

Skor koabundansi yang didominasi oleh Clostridiales (genus Lachnospiraceae dan lainnya, taksa Clostridiales-unclassified) dikaitkan dengan skor ASQ pada domain komunikasi yang lebih buruk $(\beta,-1,12$; 95\% CI, -2,23 hingga -0,01; $\mathrm{P}=0,05)$ ( $[\mathrm{OR}], 1,69$; $95 \% \mathrm{CI}, 1,06$ hingga 2,68), dan domain personal dan sosial $(\beta,-1,44 ; 95 \% \mathrm{CI},-2,47$ hingga $-0,40 ; \mathrm{P}=$ $0,01)(\mathrm{OR}, 1,96 ; 95 \% \mathrm{CI}, 1,22$ hingga 3,15$)$ untuk per unit peningkatan skor koabundansi. Sementara skor koabundansi yang didominasi Bacteroides dikaitkan dengan skor domain motorik halus yang lebih buruk $(\beta,-2,42$; CI 95\%, -4.29 hingga $-0.55 ; \mathrm{P}=0,01)(\mathrm{OR}$, 1,52 ; $95 \%$ CI, 1,07 hingga 2,16) per unit peningkatan skor koabundansi. Hasil studi ini membuktikan bahwa terdapat hubungan antara mikrobiota saluran cerna dimasa usia bayi dengan berbagai kemampuan perkembangan anak pada usia 3 tahun. ${ }^{23}$
Pemberian probiotik juga dikaitkan dengan kualitas hidup anak. Pada sebuah studi uji acak terkontrol ditunjukkan bukti bahwa pemberian Bifidobakterium dengan kombinasi yang terdiri dari Bifidobakterium longum BB536 (3x109 CFU), Bifidobakterium infantis M-63 (1x109 CFU), dan Bifidobakterium breve M-16 $\mathrm{V}$ (1x109 CFU) dalam bentuk bubuk $3 \mathrm{mg}$ sachet yang diberikan sehari sekali selama 8 minggu, pada anak berusia sekitar 9 tahun dengan rinitis alergi dan asma intermitten, ternyata tidak hanya dapat mengurangi gejala alergi, tetapi juga dapat secara signifikan meningkatkan skor kualitas hidup (yang dinilai menggunakan Mini Rhinoconjunctivitis quality of life questionnaire) dibandingkan pada kelompok anak yang tidak mendapatkannya. ${ }^{24}$

\section{Mekanisme Bifidobacterium dalam pencegahan gangguan tumbuh kem- bang anak}

Berbagai studi yang bermaksud mengungkap komunikasi antara mikrobiota saluran cerna dan otak menunjukkan hasil yang bervariasi dalam hal mekanisme yang digunakan tubuh manusia untuk merespon bakteri komensal dan patogen. ${ }^{25}$ Teori Gut-brain axis merupakan gambaran adanya sebuah aksis atau jalur komunikasi dua arah antara sistem saraf pusat atau otak dengan saluran intestinal. Aksis ini mempunyai tiga jalur utama, yaitu jalur neuronal atau persarafan, jalur hormonal, dan jalur imunologi. Berdasarkan mekanisme tiga jalur utama tersebut, mikrobiota saluran cerna akan berperan dalam perkembangan otak dan tumbuh kembang anak. ${ }^{26}$

Perkembangan neuron otak bersifat adaptif yang dipengaruhi oleh faktor genetik dan lingkungan. Sementara perkembangan komposisi mikrobiota berjalan paralel dan mempunyai sebuah "periode kritis" yang sama dengan perkembangan perkembangan otak pada usia dini, dan sebaliknya. ${ }^{27}$

Mikrobiota dapat menyekresi berbagai neurotransmiter (misalnya: $\gamma$-aminobutyric acid atau GABA) yang akan memicu sel-sel saluran cerna untuk melepaskan sejumlah molekul untuk memodulasi sinyal persarafan pada jalur produksi neuro-metabolit pada sistem saraf enterik, sistem saraf pusat dan perifer. Mikrobiota juga dapat mensekresi short-chain fatty acids (SCFAs) yang akan menginduksi sel-sel neuro- 
endokrin untuk mengonversi asam amino menjadi serotonin, yang nantinya akan berfungsi dalam komunikasi antara otak dan saluran cerna melalui jalur neuro-endokrin. ${ }^{26}$

Jalur aktivasi imun akan terjadi bila permeabilitas intestinal meningkat, berisiko akan terlepasnya bakteri patogen ke dalam sirkulasi. Hal ini akan memicu respons berupa peningkatan produksi molekulmolekul imun inflamatori (misalnya: IL-6 atau IL-10) dan antibodi (misalnya: $\operatorname{IgA}$ ) yang akan mengirimkan sinyal ke otak. ${ }^{26}$

Untuk jalur komunikasi melalui persarafan, diperankan oleh n.vagus. Sinyal dari otak akan memengaruhi fungsi sensoris, motoris, dan sekretoris dari intestinal, dan mikrobiota di dalam saluran cerna akan mengirimkan informasi balik ke otak tentang motilitas dan komposisi saluran cerna melalui jalur vagal aferen. ${ }^{26}$

Studi pada anak ASD juga menunjukkan peningkatan SCFA dan 50-HT yang diproduksi oleh mikrobiota. Peningkatan kadar 50-HT akan menyebabkan penurunan triptofan dan hiperserotonemia yang memengaruhi kemunculan berbagai gejala gastrointestinal. Pada anak ASD juga bisa menunjukkan peningkatan permeabilitas intestinal yang menyebabkan difusi pasif berbagai metabolit dan LPS bakteri melalui barier intestinal. Akibatnya, akan terjadi peningkatan sitokin pro-inflamasi (Misalnya: IL-1B, IL-6, IL-8, dan IL-12p40) yang berhubungan dengan berbagai gangguan perkembangan dan komunikasi sosial. ${ }^{12}$

Pada saat yang sama, akan terjadi mekanisme gut-brain axis melalui n.vagus dan aksis-HPA yang memengaruhi reseptor kemo- dan mekano-vagal yang berada di villi-villi mukosa, dan kadar kortisol sistemik yang memengaruhi munculnya eksasebarsi gejala-gejala gastrointestinal dengan konsekuensi kemungkinan juga akan memengaruhi pola perilaku yang ditampilkan oleh anak. ${ }^{12}$

Berbagai faktor lingkungan yang memengaruhi perkembangan mikrobiota saluran cerna selama masa anak usia dini juga berhubungan dengan berbagai faktor risiko ADHD. Hal tersebut memunculkan hipotesis bahwa komposisi mikrobiota selama masa bayi yang dipengaruhi oleh berbagai faktor lingkungan yang berbeda, mempunyai konsekuensi jangka panjang dalam hal mencegah atau memicu perkembangan manifestasi ADHD. ${ }^{28}$
Protein yang termasuk neurotrofin, seperti BDNF (Brain-derived neurotrophic factor), juga disinyalir mempunyai peran penting dalam patogenesis gangguan perilaku seperti ADHD. Produksi SCFA oleh mikrobiota berhubungan positif dengan kadar BDNF yang sangat dibutuhkan dalam proses neurogenesis selama periode kritis perkembangan otak anak. Hal tersebut meningkatkan SCFA melalui asupan nutrisi kaya serat yang dikombinasi dengan menciptakan komposisi mikrobiota saluran cerna yang tepat, kemungkinan akan menjadi perhatian para peneliti dalam manajemen terapi gejala ADHD di masa depan. ${ }^{22}$

\section{Kesimpulan}

Berbagai bukti telah terakumulasi tentang modulasi komposisi mikrobiota saluran cerna sebagai salah satu strategi yang potensial di masa depan untuk penanganan berbagai gangguan perkembangan otak dan tumbuh kembang anak, terutama peran khusus yang ditunjukkan oleh spesies Bifidobacterium. Namun, dari semua informasi yang menjanjikan tersebut, masih banyak ditemukan ketidak-jelasan, celah yang belum terjawab, dan inkonsistensi hasil bila dilakukan perbandingan antar studi. Perbedaan tersebut meliputi jenis/strain, dosis, durasi pemberian dari probiotik, teknik analisis komposisi mikrobiota, standarisasi instrumen penilaian fungsi otak dan perkembangan anak, desain studi, besar subyek, dan sebagainya. Masih dibutuhkan studi yang mempunyai kekuatan bukti lebih tinggi untuk mengidentifikasi berbagai mekanisme molekuler mikrobiota saluran cerna dalam memodulasi otak sehingga akan terungkap probiotik yang paling tepat sebagai agen terapeutik untuk penanganan berbagai gangguan tumbuh kembang anak.

\section{Daftar pustaka}

1. Cerdó T, Ruíz A, Suárez A, Campoy C. Probiotic, Prebiotic, and Brain Development. Nutrients 2017;9:1247.

2. Skonieczna-Zydecka K, Marlicz W, Misera A, Koulaouzidis A, Łoniewski I. Microbiome - The Missing Link in the Gut-Brain Axis: Focus on Its Role in Gastrointestinal and Mental Health. J Clin Med 2018; 7:521. 
3. Onubi OJ, Poobalan AS, Dineen B, Marais D, McNeill G. Effects of probiotics on child growth: a systematic review. J Health Popul Nutr 2015;34:8.

4. Firmansyah A, Dwipoerwantoro PG, Kadim M, dkk. Improved growth of toddlers fed a milk containing synbiotics. Asia Pac J Clin Nutr 2011;20:69-76.

5. Chouraqui JP, Grathwohl D, Labaune JM, dkk. Assessment of the safety, tolerance, and protective effect against diarrhea of infant formulas containing mixtures of probiotics or probiotics and prebiotics in a randomized controlled trial. Am J Clin Nutr 2008;87:1365-73.

6. Puccio G, Cajozzo C, Meli F, dkk. Clinical evaluation of a new starter formula for infants containing live Bifidobacterium longum BL999 and prebiotics. Nutrition 2007;23:1-8.

7. Roze JC, Barbarot S, Butel MJ, dkk. An a-lactalbuminenriched and symbiotic-supplemented v. a standard infant formula: a multicentre, double-blind, randomised trial. $\mathrm{Br} \mathrm{J}$ Nutr 2012;107:1616-22.

8. Abrahamse-Berkeveld M, Alles M, Franke-Beckmann e, dkk. Infant formula containing galacto-and fructo-oligosaccharides and Bifidobacterium breve M-16V supports adequate growth and tolerance in healthy infants in a randomised, controlled, doubleblind, prospective, multicentre study. J Nutr Sci 2016;5:e42.

9. Cerdó T, García-Santos JA, Bermúdez MG, Campoy C. The role of probiotics and prebiotics in the prevention and treatment of obesity. Nutrients 2019;11:635.

10. Abenavoli L, Scarpellini E, Colica C, dkk, Gut microbiota and obesity: a role for probiotics. Nutrients 2019;11:2690.

11. Cerano C, Da Silva BS, Monteil MA, Davis EM. Overweight and obesity in children are associated with an abundance of firmicutes and reduction of bifidobacterium in their gastrointestinal microbiota. Child Obes 2020;16:204-210.

12. Ristori MV, Quagliariello A, Reddel S, dkk. Autism, gastrointestinal symptoms and modulation of gut microbiota by nutritional interventions. Nutrients 2019;11:2812.

13. Luk B, Veeraragavan S, Engevik M, dkk. Postnatal colonization with human "infant-type" Bifidobacterium species alters behavior of adult gnotobiotic mice. PLoS One 2018;13: e0196510.

14. Pärtty A, Kalliomäki M, Wacklin P, Salminen S, Isolauri E. A possible link between early probiotic intervention and the risk of neuropsychiatric disorders later in childhood: a randomized trial. Pediatr Res 2015;77:823-828.

15. Partty A, Kalliomaki M, Endo A, Salminen S, Isolauri E. Compositional development of bifidobacterium and lactobacillus microbiota is linked with crying and fussing in early infancy. PLoS One 2012;7:e32495.

16. Lacorte E, Gervasi G, Bacigalupo I, dkk. A systematic review of the microbiome in children with neurodevelopmental disorders. Front Neurol 2019;10:727.

17. Berding K, Donovan SM. Diet can impact microbiota composition in children with autism spectrum disorder. Front Neurosci 2018;12:515.

18. Razafindralambo A, Razafindralambo H. Gut microbiota profile autism spectrum disorder relationship: diversity and imbalance in probiotics. J Prob Health 2019;7:209.

19. Xu M, Xu X, Li J, Li F. Association between gut microbiota and autism spectrum disorder: a systematic review and metaanalysis. Front Psychiatry 2019;10:473.

20. Ho LKH, Tong VJW, Syn N, dkk. Gut microbiota changes in children with autism spectrum disorder: a systematic review. Gut Pathog 2020;12:6.

21. Ng QX, Loke W, Venkatanarayanan N, Lim DY, Soh AYS, Yeo WS. A systematic review of the role of prebiotics and probiotics in autism spectrum disorders. Medicina 2019;55:129.

22. Bull-Larsen S, Mohajeri MH. The potential influence of the bacterial microbiome on the development and progression of ADHD. Nutrients 2019;11:2805.

23. Sordillo JE, Korrick S, Laranjo N, dkk. Association of the infant gut microbiome with early childhood neurodevelopmental outcomes. An ancillary study to the VDAART randomized clinical trial. JAMA Netw Open 2019;2:e190905.

24. Del Giudice MM, Indolfi C, Capasso M, dkk. Bifidobacterium mixture (B longum BB536, B infantis M-63, B breve M-16V) treatment in children with seasonal allergic rhinitis and intermittent asthma. Ital J Pediatr 2017;43:25.

25. Mohajeri MH, La Fata G, Steinert RE, Weber P. Relationship between the gut microbiome and brain function. Nutr Rev 2018;76:481-96.

26. Smith LK, Wissel EF. Microbes and the mind: how bacteria shape affect, neurological processes, cognition, social relationships, development, and pathology. Perspect Psychol Sci 2019;14:397-418

27. O' Mahony SM, Stilling RM, Dinan TG, Cryan JF. The microbiome and childhood diseases: focus on brain-gut axis. birth defects res (part C) 2015;105:297-314.

28. Cenit MG, Nuevo IC, Codoner-Franch P, Dinan TG, Sanz Y. Gut microbiota and attention deficit hyperactivity disorder: new perspectives for a challenging condition. Eur Child Adolesc Psychiatry 2017;26:1081-92. 